\title{
東濃ウラン鉱床におけるナチュラルアナログ研究 ーウラン鉱床での隆起·沈降の変遷と隆起速度の見積もりー
}

\author{
笹尾英嗣* 天野健治* 太田久仁雄*
}

\begin{abstract}
東濃ウラン鉱床はその形成時（約 1 千万年前）から隆起・侵食の影響を受けてきたにもかかわらず，大部分のウラン 系列核種は移行せずに安定に保持されている. 隆起・侵食によって生じる地質環境の水理学的・地球化学的な変化によ って, 放射性核種の化学的挙動が変化する可能性があるため, 東濃ウラン鉱床が被った隆起・侵食に伴う地質環境の変 化とその変化がウランの移行・保持に及ぼした影響を示すことにより，隆起・侵食を考慮した地層処分システムの信頼 性の向上に資することができる。そこで，隆起・侵食が地質環境にどのような影響を及ぼすかを評価する研究の一環と して，現在認められる地層の厚さから，海水準変動と不整合期の侵食量を考慮して，東濃ウラン鉱床の隆起・沈降量と 過去約 150 万年間の隆起速度を見積もった.

見積もりの結果, 隆起量としては約 150 万年前と考えられる瀬戸層群の堆積後, 現在までの期間が約 $340 \mathrm{~m}$ と最も大 きく，この間の平均隆起速度は約 $0.2 \sim 0.3 \mathrm{~mm} /$ 年と見積もられた.

ただし，隆起・沈降量の見積もりには，海水準変動と侵食量の見積もりが影響するため，これらを精度よく復元する 必要がある.また，隆起速度の見積もりには隆起に要した期間の決定精度が大きく影響し，瑞浪層群と瀬戸層群の不整 合期を例とすると，現在得られている放射年代值を用いると，見積もり結果に最大で 10 倍程度の差が生じることが明ら かになった。
\end{abstract}

Keywords : 東濃ウラン鉱床, 隆起·侵食, 層厚, 隆起速度, 変動シナリオ, ナチュラルアナログ

Though the Tono uranium deposit, central Japan, has been subjected to uplift and associated denudation since its formation at about 10 million years ago, most of the uranium has been preserved in the deposit. Uplift and denudation might result in a change of groundwater flow and the formation of oxidized zone in the shallow subsurface. Such changes of the geological environment would affect the chemistry and migration behaviour of uranium. The description of long-term uranium preservation process throughout the uplift and denudation history can contribute to enhancing the confidence in the demonstration of long-term safety of a geological disposal system.

As part of the study on how geological phenomena affect the geological environment, the amount of uplift/subsidence and vertical displacement rate were estimated from the presently observed strata thicknesses, in consideration of global sea-level change and erosion during formation of unconformities.

As a result, the quantitative estimation of uplift is about $340 \mathrm{~m}$ and was the greatest between the sedimentation of the Seto Group, which was completed at about 1.5 million years ago, and the present. The average vertical displacement rate during this period is estimated to have been in a range between 0.2 and $0.3 \mathrm{~mm} /$ year.

It is pointed out that the quantitative estimate of uplift would be affected by the estimations of sea-level during the deposition and amount of erosion during the unconformities. The accuracy of the estimated duration of the displacement affects the quantitative estimation of the vertical displacement rate. Alternative estimates of the vertical displacement rate after the Mizunami Group sedimentation, based on the known age data, would vary over an order of magnitude (about 10 times difference).

Keywords : Tono uranium deposit, uplift and denudation, thickness of strata, vertical displacement rate, perturbation scenario, natural analogue

\section{1 はじめに}

ナチュラルアナログ研究は，「放射性廃棄物の地層処分 システムにおいて発生すると想定されるプロセスに類似 する天然現象や, 地層処分システムの構成物に類似する天 然の物質などについて研究すること」とされている[1]. この研究は，「さまざまな天然現象や物質の産状を長期の 時間スケールで進行した実験結果と見なすことにより, 室 内実験では得ることのできない情報や知見を与えてくれ る唯一の方法であり, 地層処分システムの長期にわたる安 全性を確認するために欠くことのできない研究」とされて いる[1].

変動帯に位置するわが国における地層処分システムの 長期的安全性の信頼性を向上させるためには, 地質学的あ るいは水理学的事象などを個別に理解するだけでなく, そ

Natural analogue study in the Tono uranium deposit - Quantitative estimation of uplift and subsidence, and vertical displacement rate by Eiji Sasao (sasao@tono.jnc.go.jp), Kenji Amano, Kunio Ota

* 核燃料サイクル開発機構 東濃地科学センター

Tono Geoscience Center, Japan Nuclear Cycle Development Institute 于509-5102 岐阜県土岐市泉町定林寺 959-31
れら相互の関連性や, そのような複合事象が地層処分シス テムに与える影響について理解することが必要である。 と くに，放射性核種の移行・保持に影響を及ぼす因子である 水理学的・地球化学的環境は, 変動シナリオで考慮される ように，隆起・侵食や断層活動などの地質学的事象によっ て変化する可能性がある。隆起・侵食に着目すると，隆起・ 侵食によって生じる地形変化や土被りの減少は, 地下水流 動の変化や地表近くでの酸化帯の形成といった現象を引 き起こす.とくに酸化還元電位や $\mathrm{pH}$ などの地球化学的な 環境条件の変化によって, 放射性核種の化学的挙動も大き く変化する.このため, 地層処分システムの長期的安全性 を評価するためには，隆起・侵食や断層活動などの地質学 的事象が地質環境の変化に及ぼす影響や, 地質学的事象に 伴う地質環境の変化が放射性核種の移行・保持に及ぼした 影響について評価する必要がある.

岐阜県南東部の東濃地方に分布する東濃ウラン鉱床は, 約 1 千万年前と考えられるその形成時から隆起・侵食の影 響を受けてきたにもかかわらず，ウラン鉱床が地下水中に 溶け出してしまうような状態にはならなかった事例であ 
る[2]. 東濃ウラン鉱床を利用して過去から現在までに生 じた地質学的事象とそれがウランの移行・保持の状態に及 ぼした影響を明らかにすることによって, 日本列島では避 けることのできない地質環境の長期的変遷を考慮した地 層処分システムの信頼性を向上させることができる.

日本のような変動帯において, 隆起・侵食は前述のよう に, 水理学的・地球化学的環境の変化を引き起こす直接的 要因としてとくに重要である. そこで, 東濃ウラン鉱床の うち月吉鉱床を例として, その母層である瑞浪層群とそれ を被覆寸る瀬戸層群の隆起・沈降現象に着目し, 大まかな 見積もりではあるものの, 現在認められる地層の層厚から 過去から現在までの隆起速度と隆起・沈降量を見積もった ので, その結果と隆起・侵食がウランの移行・保持の状態 に与える影響について報告する.

\section{2 月吉鉱床の概要}

\section{1 地質}

東濃ウラン鉱床には 4 つの主要な鉱床があるが, そのう ち月吉鉱床が最大の鉱床である（Fig.1）。月吉鉱床では, これまでに 500 孔以上のボーリングに加え, 1970 年代初 頭に探鉱のための坑道が開削されており, 鉱床の地質学的 特徴などが詳細に把握されている. なお, 月吉鉱床では経 済性に乏しいためこれまで採鉱活動は行われなかった。

月吉鉱床の周辺には, 粗粒〜細粒黒雲母花崗岩からなる 土岐花崗岩とそれを不整合に覆う瑞浪層群, そしてこれら を不整合で覆って瀬戸層群が分布する (Fig.1)。瑞浪層群 は下位から土岐夾炭累層, 本郷累層, 明世累層, 生俵累層

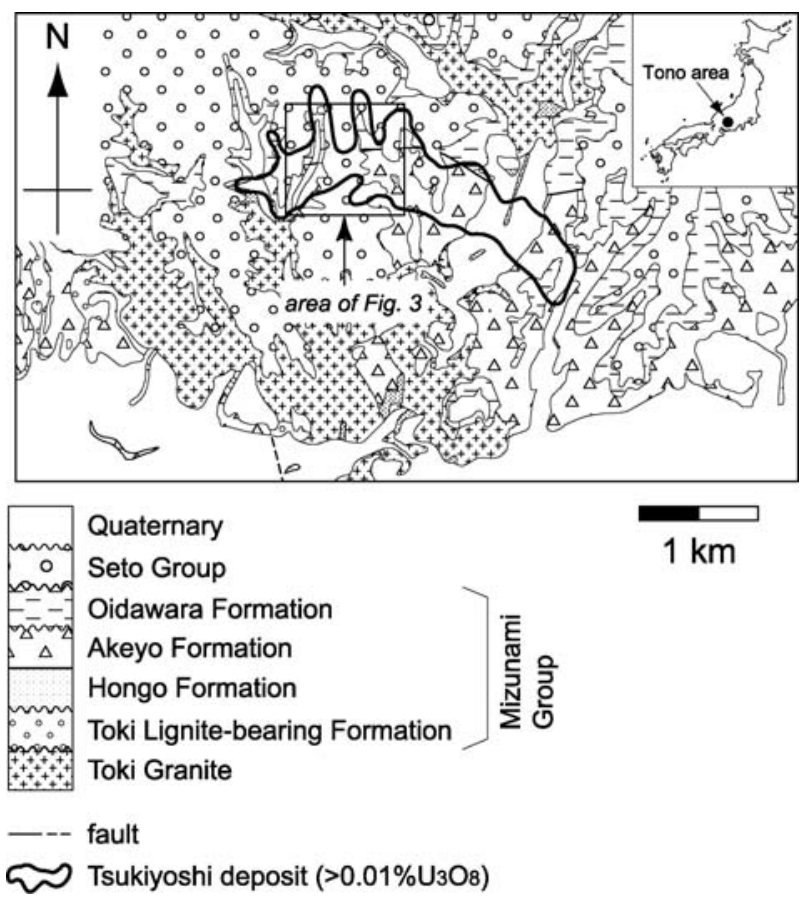

Fig. 1 Geological map around the Tono uranium deposit.
に区分される[3]（Figs.1＆2）。このうち, 土岐夾炭累層と 本郷累層, 明世累層と生俵累層の間は不整合関係にあり, 本郷累層と明世累層の間は整合関係にある（Fig.2）。月吉 鉱床は主として土岐夾炭累層中に胚胎する.

月吉鉱床およびその周辺の地質の分布および層序から， 以下のような地史が考えられる[3-7]. 約 7000 万年前にマ グマが貫入, 固結し, 基盤岩となる土岐花崗岩体が形成さ れた。この花崗岩は, ウラン含有量が領家帯の花崗岩類な ど月吉鉱床周辺に分布する地質帯と比べて高く, ウランの 供給源になったと考えられている[8]. 土岐花崗岩体の形 成以降, 地表が削剥されて花崗岩体が地表に露出したが, 約 2000 万年前になると河川が形成されるようになり，瑞 浪層群（土岐夾炭累層）の堆積が始まった。この後, 湖が 形成され本郷累層が, 後には海水が侵入し明世累層が堆積 したが，1750 万年ほど前に一旦隆起・陸化した。約 1550 万年前に水深約 100 200m の海が形成され，生俵累層が 堆積した。この海は数十万年間存在した後, 約 1500 万年 前に陸化して瑞浪層群の堆積が終了した. その後, 約 1200 万年前までの間, 瑞浪層群が侵食を受けるようになった。 さらに，約 1200 万年前になると湖が形成され，粘土や砂 が堆積するようになり, 瀬戸層群の堆積が始まった。約 1100 万年前になるとこの地域には河川が流れるようにな り，多量の砂磎を堆積させた。瀬戸層群の堆積が 150 万年 前まで続いた後, 本地域は隆起し, 多くの場所では侵食を 受けたが, 河川沿いでは段丘などが形成され，現在の地形 が形成されていった。

中部地方では, 瑞浪層群分布域を含む広い地域が, 古地 磁気方位の変化から瑞浪層群堆積中にあたる時代中に時 計回りに約 $50^{\circ}$ 回転したことが示されている[9]. これは 日本海の拡大に伴うものである。 日本海の拡大は約 1500 万年前に終了し，この時期に現在の日本列島の骨格が形成 されたと考えられており，それ以降，プレートの沈み込み はほぼ定位置で継続したとされており[10]，現在の広域的 なテクトニクスの影響下に置かれたと考えられる.

\section{2 月吉鉱床}

月吉鉱体は現地表下 $130 \sim 150 \mathrm{~m}$ 付近に位置し，延長約 $3.5 \mathrm{~km}$ ，幅 $500 \mathrm{~m}$ で，鉱化帯の厚さは数 $\mathrm{m}$ である。鉱量は 約 3100 トン $\mathrm{U}_{3} \mathrm{O}_{8}$ で, 品位は平均 $0.06 \%$ である[11]. ウラ ン鉱化は多くの場合, 土岐夾炭累層の河川成もしくは湖成 堆積岩中の亜炭に富む岩相で認められ，土岐花崗岩との不 整合の直上数 $10 \mathrm{~m}$ 以内に多く分布する. 鉱化帯の分布は, 基盤となる花崗岩上の古河川（月吉チャンネル）に支配さ れている.

月吉鉱床では一次鉱物としてコフィン石 $\left(\mathrm{U}\left(\mathrm{SiO}_{4}\right)_{1-\mathrm{x}}(\mathrm{OH})_{4 \mathrm{x}}\right)$ とピッチブレンド $\left((\mathrm{U}, \mathrm{Th}) \mathrm{O}_{2}\right)$ が，二 次鉱物としてジッペ石 $\left(\mathrm{K}_{4}\left(\mathrm{UO}_{2}\right)_{6}\left(\mathrm{SO}_{4}\right)_{3}(\mathrm{OH})_{10} 4 \mathrm{H}_{2} \mathrm{O}\right)$ とア ンダーソン石 $\left(\mathrm{Na}_{2} \mathrm{Ca}\left(\mathrm{UO}_{2}\right)\left(\mathrm{CO}_{3}\right)_{3} 4 \mathrm{H}_{2} \mathrm{O}\right)$ が同定されている [11].しかしながら，実際のウラン鉱床中では一次鉱物は 


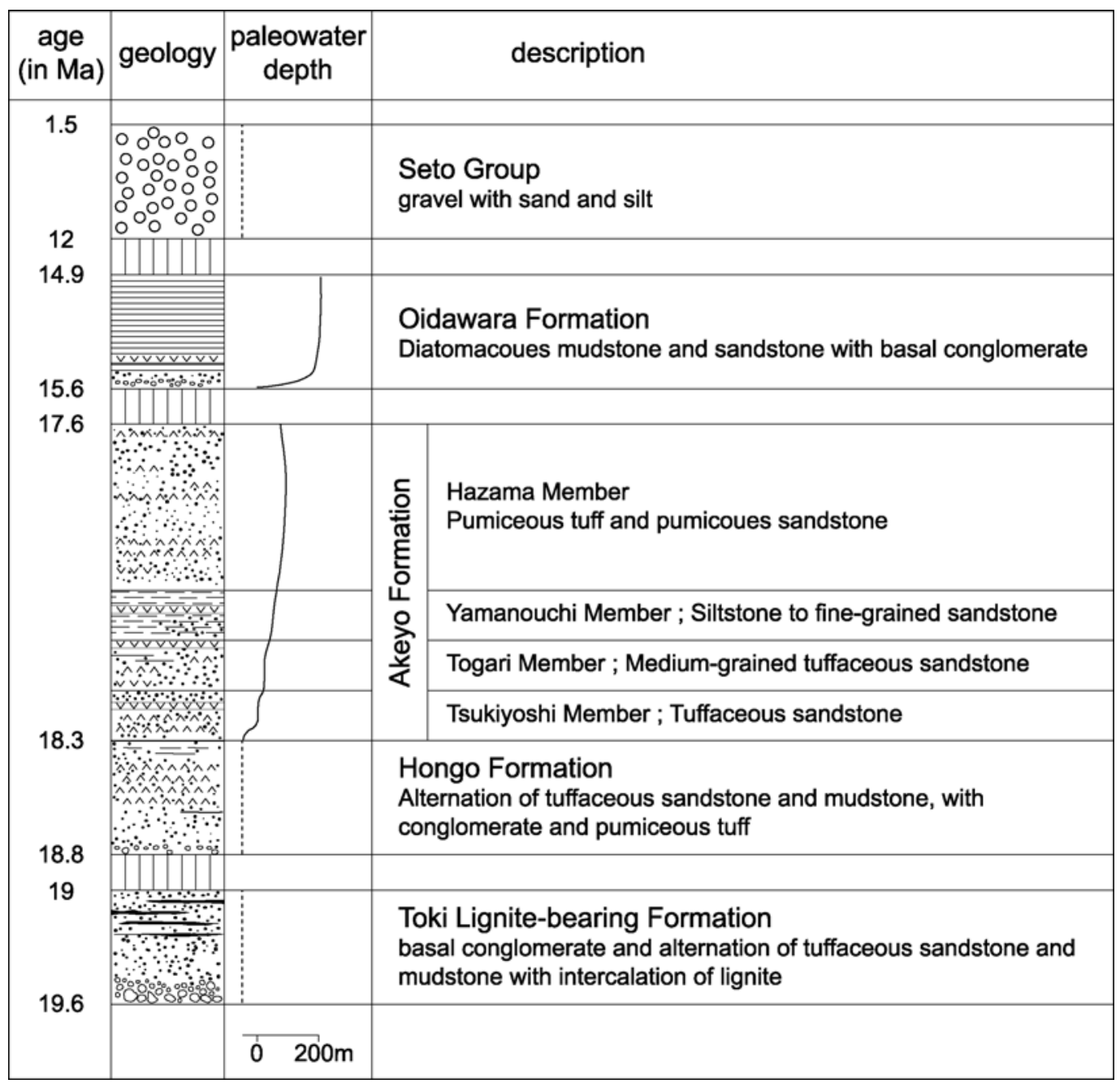

Fig. 2 Stratigraphy, description and paleo-environment of the Mizunami and Seto Groups (age data and paleowater depth are referred to literatures $[3,5,7])$.

少量であり，ウラン系列核種は粘土鉱物，黄鉄鉱，黒雲母 や炭質物などに収着, 濃集していると考えられる[2].

ウランは基盤の土岐花崗岩から供給されたと考えられ ている. 寸なわち, 土岐花崗岩上部の風化帯から酸化的な 地下水によってウランが溶脱され, その地下水が堆積岩中 に入り, 還元的になることによってウランが沈殿したと考 えられている. ウラン鉱床の成因については未だ不明な点 が多いが, ウランの沈殿は堆積岩の堆積後に生成した粘土 鉱物などによる収着もしくは酸化還元過程を伴った作用 や硫酸還元を伴った有機物の分解一黄鉄鉱の形成に伴っ たものであると考えられている[12-14]. なお，これまでの ところ月吉鉣床は，ジルコンを用いたフィッション・トラ ック年代（以下, FT 年代）に基づいて約 1000 万年前に形 成されたと考えられている[15].

ウラン鉱床形成後のウラン系列核種の移行・保持につい ては, 鉱床スケールから $1 \mathrm{~m}^{3}$ 岩塊のスケールまでを対象に ウラン系列核種の同位体測定などが行われ, 過去 100 万年
間にはウランはほとんど移動していないものの, ラジウム は過去 1 万年間に少なくとも数 $\mathrm{m}$ は移動していることが 明らかになった。これにより，現ウラン鉱床中のウランお よび娘核種の大部分は長期間にわたって安定に存在した ことが示され，還元的な環境の維持が大きく関与している ことが示されている[4,15-16].

現在のウラン鉱床では, ウランは石英や長石類, 岩片な どの砕屑性粒子の間の空隙中あるいはその周囲および黒 雲母の䢃開沿いに濃集している [17-18]. また，同様の鉱 物組成であっても, ウラン濃集部の堆積岩は透水係数が高 いのに対し, ウラン非濃集部の堆積岩では透水係数が低い 傾向が認められている[17]. 低透水性の堆積岩と高透水性 の堆積岩を用いたウラン収着試験結果から, ウラン非濃集 部の低透水性の堆積岩の方がより多くのウランを収着で き, ウラン濃集部の堆積岩はそれ以上ウランを収着させる 能力を有していないことも示されている.このことは, ウ ランの濃集度の違いは堆積岩の収着能力の差よりも, むし 
ろウランを含む地下水が通過したかどうかの違いに依存 しているものと推察されている[19].

\section{3 月吉鉱床の隆起·沈降量}

\section{1 隆起·沈降量の推定方法}

月吉鉱床で認められる地層のうち, 生俵累層の厚さは東 濃鉱山周辺では約 40m である. 生俵累層は水深 100〜 200m の海に堆積したと考えられている[3]. ここで海水準変動 を考慮せず, 生俵累層堆積中に水深は $200 \mathrm{~m}$ でその変化が なかったと仮定すると, 生俵累層堆積中には約 $40 \mathrm{~m}$ の沈 降があったと推定できる.

生俵累層とその上位にある瀬戸層群との関係は不整合 であり, 生俵累層堆積後に現在の東濃鉱山周辺地域は陸化 して, 生俵累層が侵食されたことがわかっている[3-4]. し たがって, 生俵累層堆積後に過去の水深分（200m）は隆 起したと考えることができる. ただし, 不整合期には地層 が削られるので, 現在認められる地層の厚さは, 堆積時の 地層の厚さよりも薄くなっている. このため, 隆起量とし ては過去の水深分に加え, 不整合期に削剥された地層の厚 さを足した量と推定できる.

このように，現在見られる地層の厚さ（層厚）と地層が 堆積したときの水深から, 過去の沈降量を見積もることが できる.また, 不整合期の削剥量を考慮することによって, 隆起量を見積もることができる. 本研究では, このような 方法を用いて堆積岩の層厚と地層が堆積した水深から隆 起・沈降量を概算した.

\section{2 使用したデータ}

\subsection{1 地層の堆積年代}

瑞浪層群の堆積年代に関する研究は, 堆積年代の決定に 有効な微化石を産出する瑞浪層群上部を対象としたもの が多い。ここでは最初に瀬戸層群の年代を述心゙, 次に瑞浪 層群の上部から下部に向かって, 従来の研究成果をとりま とめ，本研究で使用する各層の年代を述べる。

（1）瀬戸層群

瀬戸層群は下位の土岐口陶土層と上位の土岐砂礫層に 区分される[20]. 瀬戸層群の年代は，月吉鉱床の西方の岐 阜県多治見市周辺の土岐口陶土層と土岐砂䃋層に挟まれ る凝灰岩の $\mathrm{FT}$ 年代に基づいて推定されており, 土岐口陶 土層と土岐砂碩層の境界の年代は 10.5 10.9Ma の間に入 るとされている[5]. 瀬戸層群基底の年代は, 土岐口陶土 層とほぼ同じ岩相で同様な層厚を有する瀬戸陶土層が 100 万年かそれより若干長い期間をかけて堆積したと見 られることから, おおよそ $12 \mathrm{Ma}$ と推定されている[5]. ま た, 瀬戸層群の上限の年代は, 土岐砂礫層中の凝灰岩の $\mathrm{FT}$ 年代と土岐砂礫層基底の推定年代の年代差および基底 から凝灰岩までの地層の厚さを用いて平均堆積速度を求
め, 土岐砂硫層堆積中の平均堆積速度が一定だったとの仮 定によって, 土岐砂礫層の厚さと平均堆積速度から $1.5 \mathrm{Ma}$ と見積もられている[5].

月吉鉱床分布域の瀬戸層群の分布は, 上述の多治見市周 辺の瀬戸層群に連続することから, 本研究では瀬戸層群の 堆積年代を 1.5〜12Ma とした.

（2）生俵累層

生俵累層加産出する浮遊性有孔虫化石[21]员, 生俵 累層は古地磁気層序の Chron C5Bn（14.800～15.155Ma； 古地磁気年代は Cande and Kent[22]に基づく）を含む時代 に堆積したと考えられる[23]. 古地磁気測定では逆帯磁が 報告されており [9], 有孔虫化石から生俵累層（の少なく とも一部）は Chron C5Bn を含むことから，この逆帯磁は Subchron C5Bn1r（14.888～15.034Ma）に対比されている [23]. また，生俵累層下部に挟在する凝灰岩からは13.9土 $1.6 \mathrm{Ma}$ の $\mathrm{FT}$ 年代が報告されている[24].

氏原ほかはこれらに基づいて生俵累層の年代を 14.9〜 15.6Ma としており[7], 本研究でもこの年代を用いる.

(3) 明世累層

明世累層からは, 珪藻化石群集の Crusidenticula sawamurae 帯に対比される珪藻化石が産出する[25]. この 化石帯の年代は 16.9〜18.4 Ma とされている[26]. 古地磁 気測定では, 明世累層中部から下部にかけてはすべて逆帯 磁を示すことが報告されている[23]. この逆帯磁は, 珪藻 化石から推定される年代を考慮すると, 古地磁気層序の C5Cr（16.726〜17.277Ma）もしくは C5Dr（17.615〜 $18.281 \mathrm{Ma}$ ）に相当すると考えられる.また, 明世累層の狭

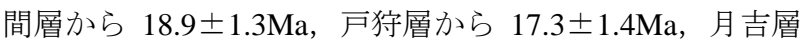
から 17.1土1.2Ma の FT 年代が報告されている[24].

氏原ほかはこれらのデータに基づいて, 明世累層の年代 をおおよそ17.6〜18.3Ma としており[7]，本研究でもこの 年代を用いる.

(4) 本郷累層

本郷累層からは年代決定に有効な微化石は報告されて いないが，本層下部の火山碩凝灰岩から 20.0土1.5Ma の FT 年代が報告されている[24]. また, 古地磁気測定では正 帯磁が報告されている[9].

氏原ほかはこれらのデータに基づいて本郷累層を古地 磁気層序の C5En（18.281～18.781Ma）に対比し，本郷累 層の年代を 18.3〜18.8Ma としており[7], 本研究でもこの 年代を用いる。

（5）土岐夾炭累層

土岐夾炭累層については，本層上部の凝灰岩から 18.3 $\pm 1.1 \mathrm{Ma}$ の $\mathrm{FT}$ 年代が報告されている[24]. 本層から産出 する植物化石は阿仁合型植物群に属するとされている [27]. 阿仁合型植物群の産出上限の年代は $17 \sim 18.5 \mathrm{Ma}$ と 考えられており [28], 土岐夾炭累層の年代はこれよりも古 いと考えられる.

土岐夾炭累層に対比される, 月吉鉱床の北西方に分布す 
Table 1 Description of the Mizunami and Seto Groups

\begin{tabular}{|c|c|c|c|c|c|}
\hline geological unit & $\begin{array}{c}\text { depositional age } \\
\text { (upper \& lower ages) }\end{array}$ & sea-level & $\begin{array}{l}\text { maximum } \\
\text { thickness }\end{array}$ & $\begin{array}{l}\text { depositional } \\
\text { environment }\end{array}$ & depth of water \\
\hline \multirow{2}{*}{ Seto Group } & $1.5 \mathrm{Ma}$ & $-50 m$ & \multirow{2}{*}{$70 \mathrm{~m}$} & \multirow{2}{*}{ fluvial } & \multirow{2}{*}{$0 \mathrm{~m}$} \\
\hline & $12.0 \mathrm{Ma}$ & $+50 \mathrm{~m}$ & & & \\
\hline \multirow{2}{*}{ Oidawara Formation } & $14.9 \mathrm{Ma}$ & $+150 \mathrm{~m}$ & \multirow{2}{*}{$160 \mathrm{~m}$} & \multirow{2}{*}{ marine } & 200 m (upper) \\
\hline & 15.6 Ma & $+60 \mathrm{~m}$ & & & $100 \mathrm{~m}$ (lower) \\
\hline \multirow{2}{*}{ Akeyo Formation } & 17.6 Ma & $+110 \mathrm{~m}$ & \multirow{2}{*}{$135 \mathrm{~m}$} & \multirow{2}{*}{ marine } & $100 \mathrm{~m}$ (upper) \\
\hline & $18.3 \mathrm{Ma}$ & $+130 \mathrm{~m}$ & & & 50 m (lower) \\
\hline \multirow{2}{*}{ Hongo Formation } & 18.3 Ma & $+130 \mathrm{~m}$ & \multirow{2}{*}{$70 \mathrm{~m}$} & \multirow{2}{*}{ lacustrine } & \multirow{2}{*}{$10 \mathrm{~m}$} \\
\hline & $18.8 \mathrm{Ma}$ & $+120 \mathrm{~m}$ & & & \\
\hline \multirow{2}{*}{ Toki Lignite-bearing Formation } & $19.0 \mathrm{Ma}$ & $+120 \mathrm{~m}$ & \multirow{2}{*}{$140 \mathrm{~m}$} & \multirow{2}{*}{ fluvial or lacustrine } & \multirow{2}{*}{$0 \mathrm{~m}$} \\
\hline & $19.6 \mathrm{Ma}$ & $+100 \mathrm{~m}$ & & & \\
\hline
\end{tabular}

る瑞浪層群中村累層は，FT 年代に基づいて 18.4〜 19.6Ma に堆積したと考えられている[29]. 本層から報告された $\mathrm{FT}$ 年代[24]は, 誤差を考慮すれば中村累層の堆積年代の範 囲に入る。

本研究では, 土岐夾炭累層と上位の本郷累層は不整合関 係にあること, 中村累層と本郷累層の堆積年代を考慮し, 土岐夾炭累層の堆積年代を 19〜19.6Ma とする.

\section{2 .2 海水準変動}

本研究で対象とする瑞浪層群が堆積し始めた約 2000 万 年前から現在までの期間を含む時期の海水準変動は, Haq et al.等によって求められている[30]. 本研究では, Haq et al. によって図示されている海水準変動曲線[30]から, 前節で 述べた各層の年代における海水準を読み取り, 各層堆積時 の海水準とした（Table 1).

\subsection{3 地層堆積時の標高と水深}

(1) 瑞浪層群

瑞浪層群堆積時の古水深は, 明世累層と生俵累層から産 出する貝化石と底生有孔虫化石に基づいて推定されてい る[31-33]. このうち糸魚川・柴田は, 貝化石群集から推定 される明世累層と生俵累層堆積時の水深の変化を図示し ている[31]. そこで, 両累層堆積時の古水深を, 各累層の 堆積開始時 (下部) と各累層の堆積終了時 (上部) で変化 させた（Fig. 2 および Table 1 参照).

土岐夾炭累層と本郷累層からは古水深決定に有効な化 石が産出しない.このうち, 本郷累層は湖成堆積物である が, 本郷累層から明世累層にかけて一連の海進を示してい ると考えられている[3]. 本郷累層から明世累層の堆積期 には，植物化石から温暖化が進んだと見られ[28], それに よって海水準が上昇したと推察される. そこで, 本郷累層 堆積後の湖水面の標高を当時の海水準の高さと同じ標高 と仮定した. 土岐夾炭累層堆積時の標高に関する情報は得 られていないため, 堆積当時の海水準の高さと同じと仮定 した. また, 水深に関しては, 土岐夾炭累層堆積時の水深
を $0 \mathrm{~m}$, 本郷累層堆積時の水深を $10 \mathrm{~m}$ と仮定した。

隆起・沈降量の見積もりに用いた古水深のデータおよび 各層の堆積環境を Table 1 に示す. また, 各層の古水深の 変化はFig. 2 に示されている.

(2) 瀬戸層群

月吉鉱床周辺には，土岐口陶土層は分布せず，土岐砂碟 層のみが広く分布する.土岐砂碩層は扇状地堆積物とされ ている[34]. 土岐砂礫層当時の古地理は十分に復元されて はいないが，月吉鉱床の北方から流下寸る河川が，南西方 〜西方に存在した東海湖に流れ込んでいたと推測されて いる[35]. 土岐砂碟層を堆積させた扇状地は月吉鉱床北方 の見行山付近を扇頂とし，長さは $10 \mathrm{~km}$ 以上に及ぶもので あったと考えられている[34].

扇状地は山地と平地の境界に形成されるが，このような 規模の大きな扇状地として, 現在の木曾川水系の犬山扇状 地（長さ約 15km）が挙げられる. 犬山扇状地では, 扇頂 部の標高は約 $40 \mathrm{~m}$ ，扇端は約 $10 \mathrm{~m}$ である，そこで，規模 の類似性から, 土岐砂礫層堆積時の扇状地の標高を犬山扇 状地と同等であったと考え, 土岐砂碟層堆積時の標高を犬 山扇状地の扇頂と扇端の標高の中間の海水準プラス $25 \mathrm{~m}$ と仮定し，当時の水深は $0 \mathrm{~m}$ とした.

\subsection{4 不整合期における地層の削剥量}

不整合期には，堆積物の上面が水面上に露出し，堆積物 は削剥を受ける。このため，現在観察される層厚は，堆積 時の地層の厚さから, 削剥された地層の厚さを差し引いた ものである. 本研究で対象とする瑞浪層群と瀬戸層群に関 しては, 土岐夾炭累層と本郷累層, 明世累層と生俵累層, 生俵累層と瀬戸層群の間は不整合であり，したがって土岐 夾炭累層と明世累層, 生俵累層で現在認められる層厚は, 堆積時の層厚よりも薄くなっている.

現状では削剥量を精密に見積もることは困難であるも のの, 広域での地層の分布と地層堆積時の古環境や古地理 から削剥量を概算することができる，最初に，生俵累層を 対象とした削剥量の概算の方法を述べる.生俵累層は深度 
100〜200m の海に堆積したと考えられている.このような 海はある程度の広がりを有していたと考えられ, 生俵累層 堆積時の層厚は瑞浪盆地内ではそれほど大きく異ならな かったと推察される. 現在観察される生俵累層の層厚は場 所によって異なるが，これは削剥を受けた結果であり，生 俵累層堆積後の削剥の量が異なっていたためと考えられ る. そこで本研究では, 堆積時の層厚を現在認められる生 俵累層の最大層厚とし, それから現在認められる層厚を差 し引いた分が削剥されたと考えることにより, 削剥量を概 算した. 生俵累層堆積時の層厚は, 現在観察される最大層 厚である $160 \mathrm{~m}[3]$ とた。

明世累層堆積後の不整合期については，以下の考えを 用いた. すなわち, 本郷累層と明世累層は整合関係にあり, 本郷累層堆積後には削剥は生じなかったと考えられるに もかかわらず, 後述するように東濃鉱山で観察される本郷 累層の層厚は，月吉断層の北側で約 $30 \mathrm{~m}$, 南側で約 $45 \mathrm{~m}$ であり, 瑞浪地域で観察される本郷累層の最大層厚に比べ て小さい. 本郷累層は湖の堆積物であり, 場所によって堆 積物の厚さが異なっていた可能性がある. 明世累層は浅海 性の堆積物であり，本郷累層と同様のことが言える．東濃 鉱山で認められる本郷累層の層厚は, 月吉断層の北側で最 大層厚の $40 \%$ 程度, 南側で $65 \%$ 程度である. そこで, 東 濃鉱山における明世累層堆積時の層厚を, 同層の最大層厚 の 40\%（月吉断層北側）および 65\%（月吉断層南側）と 仮定して, 削剥量を算出した. 明世累層の最大層厚は $135 \mathrm{~m}$ である[3].

土岐夾炭累層は基盤岩上に刻夕込まれた古河川を埋設 した堆積物であり [3], 場所によって堆積時の層厚が異な っていたと推察される.このため, 土岐夾炭累層堆積後の 不整合期における削剥量の見積もりには, 上述した方法は 適用できない. しかし, 土岐夾炭累層と本郷累層の間の堆 積年代の差は小さく，不整合の規模は，上述の明世累層お よび生俵累層堆積後の不整合と比べて, 小さかったと推定 されるので, ここでは土岐夾炭累層堆積後の削剥による層 厚の減少は考慮しない.

瀬戸層群については，現在の削剥量は不明であるため， 本研究では現在の削剥を考慮しない. なお, 月吉鉱床周辺

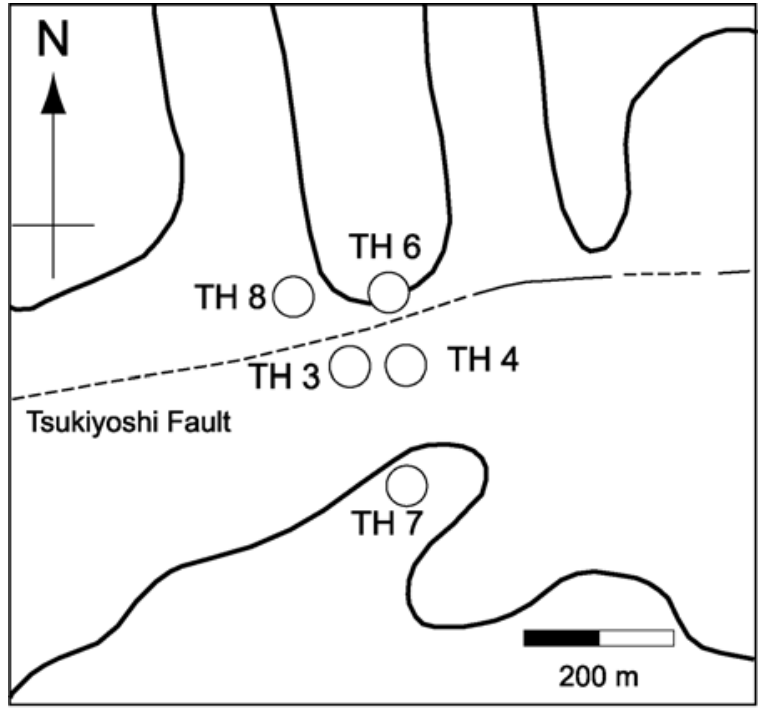

Fig. 3 Location map of bore holes studied

での瀬戸層群の最大層厚は土岐口陶土層と土岐砂碩層を あわせて $100 \mathrm{~m}$ 程度とされる[5].

\subsection{5 検討に用いた地層の層厚}

地層の層厚は, 東濃鉱山で行われたボーリング調査で作 成された地質柱状図から求めた。使用したボーリングは 5 孔で，月吉鉱床を横切る月吉断層の北側に 2 孔（TH-6 と TH-8) と南側に 3 孔 (TH-3〜4, TH-7) が位置する (Fig. 3).

ボーリング・コア記載時に行われた層序区分に基づいて 各層の層厚を求めた（Table 2)。 なお，月吉断層を挟んで 生俵累層と明世累層の層厚に相違が認められることが知 られている[36]. このため, 層厚の算出あたっては, 月吉 断層北側と南側に分けて個々のボーリング孔で求めた層 厚の平均值を各層の層厚とした（Table 2).

Table 2 から, 月吉断層南側では生俵累層が分布しない ことがわかる.また, 明世累層と本郷累層の層厚は断層北 側で厚くなっている.このような断層を挟んでの地層の分 布と層厚の变化は月吉断層の活動によるものと推察され ており[36]，生俵累層は月吉断層南側にも堆積したものの， 同累層堆積後の侵食によって削剥されてしまったと考え

Table 2 Thickness of each stratigraphical units observed in the studied bore holes.

\begin{tabular}{|c|c|c|c|c|c|c|c|c|}
\hline & \multirow[b]{2}{*}{ geological unit } & \multicolumn{5}{|c|}{ thickness (m) } & \multicolumn{2}{|c|}{ average thickness (m) } \\
\hline & & TH-6 & TH-8 & TH-3 & TH-4 & TH-7 & $\begin{array}{c}\text { north of Tsukiyoshi Fault } \\
\text { (TH-6 \& 8) } \\
\end{array}$ & $\begin{array}{c}\text { south of Tsukiyoshi Fault } \\
\text { (TH-3, } 4 \text { \& } 7) \\
\end{array}$ \\
\hline & Seto Group & 43 & 12 & 26 & 38 & 37 & (43) & (38) \\
\hline \multirow{4}{*}{ 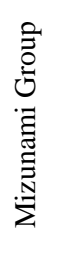 } & Oidawara Formation & 46 & 39 & 0 & 0 & 0 & 43 & 0 \\
\hline & Akeyo Formation & 29 & 27 & 48 & 41 & 53 & 28 & 48 \\
\hline & Hongo Formation & 29 & 28 & 49 & 60 & 28 & 28 & 46 \\
\hline & $\begin{array}{l}\text { Toki Lignite-bearing } \\
\text { Formation }\end{array}$ & 17 & 33 & 38 & 36 & 18 & 25 & 31 \\
\hline
\end{tabular}


られる. そこで, 月吉断層南側については, 生俵累層が堆 積したものの，その後，削剥されたと見なした．

\section{2 .6 考慮しなかったデータ}

本研究では, 不整合期の古地形面の標高と圧密による層 厚の減少を考慮しなかった。

不整合期の古地形面は, ボーリングの地質記載や電気探 査等の物理探査等により推定することは可能である. しか し, 古地形面の標高を復元することはできないため, 本研 究では不整合期の古地形面の標高を考慮しない.

圧密は, 堆積物の間隙が減少してその密度の増加する現 象であり, これによって地層の厚さは減少する. 瑞浪層群 では圧密による層厚の減少の実測例がないため, 本研究で は層厚の減少を考慮しなかった。

\section{3 隆起-沈降量の見積もり結果}

東濃鉱山で掘削されたボーリングから求めた層厚デー タを用いた隆起・沈降量の推定結果を Table 3 に示す.ま た, Fig. 4 には瑞浪層群基底面の標高変化を示した．この 結果, 月吉鉱床では堆積岩が堆積し始めてから現在までに 3 回の沈降と隆起のサイクルが認められ, 隆起量としては 約 150 万年前と推定される瀬戸層群の堆積後から現在ま での期間で約 $340 \mathrm{~m}$ と最も大きいと推定された（Table 3, Fig.4).

生俵累層堆積後の不整合期には, 240〜 280m 程度隆起し たと見積もられたが, 月吉断層南側の隆起量は, 北側に比
べて約 40m 大きく見積もられている（Table 3, Fig.4）. 月 吉断層は生俵累層堆積後に逆断層運動が生じ, 断層上盤に あたる南側が，下盤にあたる北側に比べて相対的に上昇し ており, その累積変位量は約 40～50m とされている[36]. つまり，月吉断層の上盤にあたる南側では，月吉鉱床の隆 起量と, 断層の累積変位量である約 40〜 $50 \mathrm{~m}$ とを合計し た量が見かけの隆起量として求められていることになる. したがって, 月吉断層南側での隆起量は, 本研究での見積 もり值から月吉断層の累積変位量を差し引いた量であり, 断層北側と同じく約 $240 \mathrm{~m}$ と見積もられる.

\section{4 瀬戸層群堆積後の隆起速度}

月吉鉱床の近傍を流れる土岐川流域では, 現河川との比 高が約 40m, 30〜15m, 約 $5 \mathrm{~m}$ の少なくとも 3 段の河岸段 丘が識別される.このような複数段の段丘が発達する場合 には, 段丘の形成年代と現河川との比高から隆起速度を求 めることができる[2]. しかし，土岐川流域の河岸段丘の 形成年代が不明であり, この方法によって隆起速度を求め ることはできない.

月吉鉱床では, 前章で述べたように, 瀬戸層群の堆積以 降から現在にかけて大きく隆起していると考えられる. 月 吉鉱床を含む岐阜県東濃地方に分布する瀬戸層群には, 土 岐面と呼ばれる平坦面が形成されている[37-38]. 土岐面の 成因については，堆積面であるとする考え[37], 瀬戸層群 堆積末期の平坦化作用によって形成された堆積面と浸食

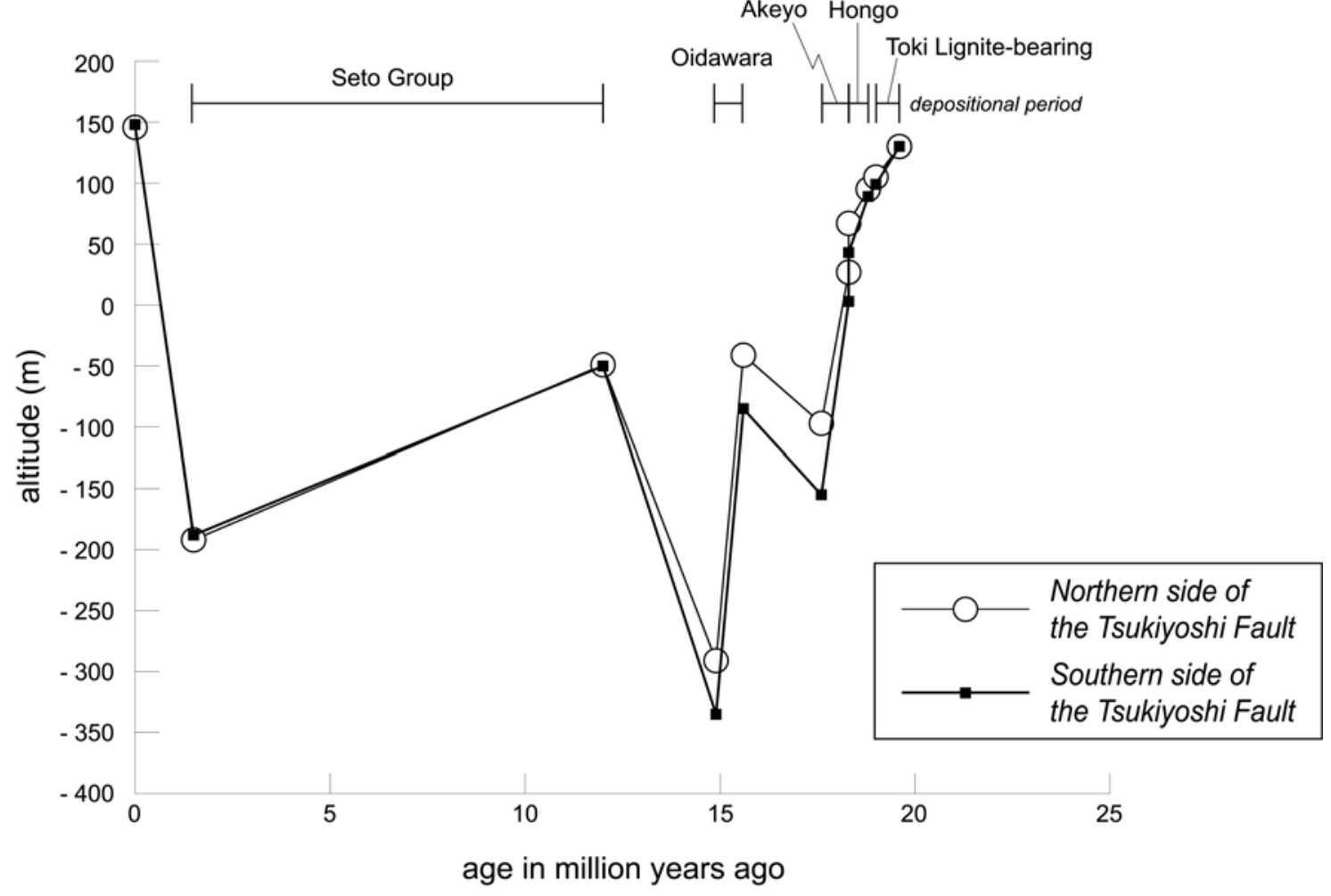

Fig. 4 Quantitative estimation of change of the basal altitude of the Mizunami Group. 


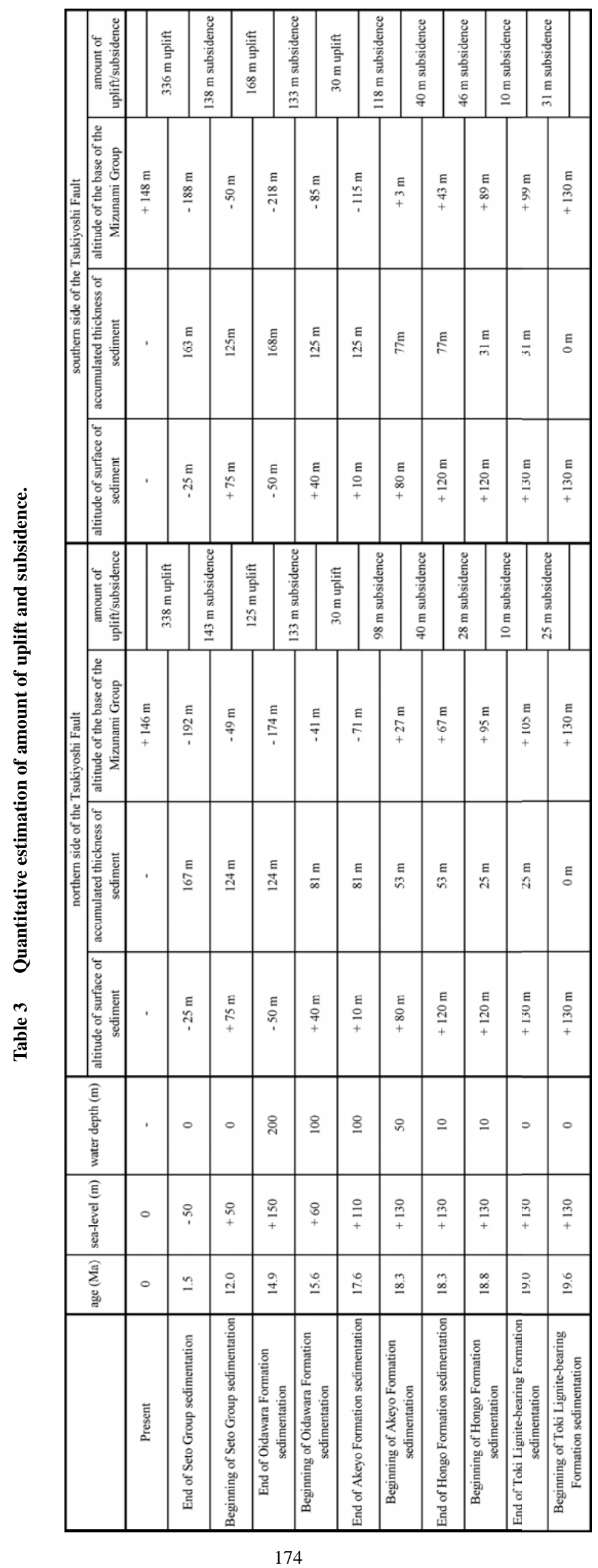


面の両方の性格を持つ地形面とする考え[38]など諸説が あるが, 近年では, 土岐面は小起伏侵食面と呼ばれる起伏 の小さな侵食面とされている[34]. つまり, 瀬戸層群の堆 積後, 侵食によって平坦面が形成された時期があったこと を示す. 土岐面の形成時期は，月吉鉱床の北東方に分布す る上野玄武岩と瀬戸層群の層序関係, および瀬戸層群を覆 う上野玄武岩の $\mathrm{K}-\mathrm{Ar}$ 年代に基づいて約 100 万年前である とされている[34]. そこで, 瀬戸層群堆積後の隆起が約 100 万年前に始まったと仮定すると, 平均隆起速度は $0.34 \mathrm{~mm} /$ 年と計算される.

月吉鉱床周辺における瀬戸層群の堆積終了年代は約 150 万年前と推定されている[5]. 仮に, 月吉鉱床周辺地域 が瀬戸層群堆積後, 速やかに隆起し始めたとすると, 前章 で求めた隆起量（約 340m）とこの年代值から現在までの 平均隆起速度は $0.23 \mathrm{~mm} /$ 年と計算される. 以上より, 本研 究で対象としたボーリング孔の位置においては, 瀬戸層群 堆積以降の平均隆起速度は約 $0.2 \sim 0.3 \mathrm{~mm} /$ 年程度と見積も られる. なお, 日本列島の過去 10 万年間の隆起速度は, 月吉鉱床周辺では $0.0 \sim 0.3 \mathrm{~mm} /$ 年とされており [39], 本研 究で示した過去 100 万年 150 万年間の平均隆起速度の見 積もり值にほぼ一致する.

\section{5 考察}

\section{1 見積もり値に影響を及ぼす要因の検討}

\subsection{1 地質年代の決定精度の影響}

約 1490 万年前とされる生俵累層堆積後から約 1200 万年 前とされる瀬戸層群堆積前の約 290 万年の期間に, 約 $240 \mathrm{~m}$ 隆起したと見積もられた。この期間に一様に隆起し たとすると, 平均隆起速度は $0.08 \mathrm{~mm} /$ 年となる。しかし, 仮に生俵累層の堆積後, 100 万年の間に隆起したと仮定す ると, 平均隆起速度は $0.24 \mathrm{~mm} /$ 年となる。このように, 隆 起速度の算定にあたっては, 隆起の開始と終了の時期の年 代を精度よく求めることが必要である.

生俵累層の堆積年代は同累層から産出する微化石と凝 灰岩層の $\mathrm{FT}$ 年代に基づいている. FT 年代については, 3 章で述べたように年代測定值として中央值として 1390 万 年が得られているが，それに対する誤差（1o）は土160 万年である[24]. すなわちこの年代值としては, 1550 万年 から 1230 万年の間のいずれかにあるということになる. ここで, 隆起終了時期を瀬戸層群の堆積開始時である 1200 万年前とし, 隆起開始時期を生俵累層から報告され た FT 年代值を使うと, 隆起に要した期間は 350 万年 $(1550$ 万年マイナス 1200 万年）から 30 万年（1230 万年マイナ ス 1200 万年）の範囲になる. この間に $240 \mathrm{~m}$ 隆起したと すると, その隆起速度は $0.07 \mathrm{~mm} /$ 年 $0.8 \mathrm{~mm} /$ 年となり, 1 オーダー異なる結果が得られる.

地質年代は隆起・沈降量の見積もりには影響しないが，
ここで述べたように隆起速度を検討する場合には, 地質年 代の精度が見積もり結果に大きな影響を及ぼす。したがっ て, 地質年代測定值の精度の向上や複数の手法の組み合わ せ等を行うことにより, 隆起に要した期間の把握を精度よ く行っていく必要があると考えられる.

\section{1 .2 海水準変動の影響}

海水準変動が隆起・侵食量の見積もりにどの程度影響す るかを検討するため, 瑞浪層群堆積開始時から現在までの 間, 海水準は変動せず, 海水面の標高が $0 \mathrm{~m}$ にあったと仮 定して, 隆起・沈降量の見積もりを行った（ただし，侵食 は考慮されているため, 以下では, この見積もり結果を「侵 食のみ考慮ケース」という). 月吉断層北側での見積もり 結果を Fig. 5 に示寸 (図中の $\times$ ). これと海水準変動およ び侵食を考慮したケース（以下「基本ケース」という）の 結果（Fig. 4 および Fig. 5 中の○）を比較すると，「侵食の み考慮ケース」では, 瑞浪層群堆積中には全体として標高 が低く見積もられていることがわかる．瑞浪層群堆積時

（約 1960 万年前から 1490 万年前）には, 海水準は現在よ りも50〜150m 程度高かったとされている[30]. したがっ てこの差異は, 中新世には海水準が現在よりも高かったこ とに起因すると考えられる.

ところで, 生俵累層堆積後の隆起量に着目すると,「基 本ケース」では約 $240 \mathrm{~m}$ の隆起と見積もられたのに対し, 「侵食のみ考慮ケース」では約 $340 \mathrm{~m}$ の隆起と見積もられ た. 両ケースの違いは, 海水準変動によって生じている. つまり,「基本ケース」では生俵累層堆積終了時の海水準 が+150m であったのに対し, 瀬戸層群堆積開始時の海水準 が+50m で, 約 $100 \mathrm{~m}$ の海退が生じている. 生俵累層堆積 終了時の水深は $200 \mathrm{~m}$ としており,「侵食のみ考慮ケース」 では水深の $200 \mathrm{~m}$ と地層の削剥量分（および瀬戸層群堆積 時の標高）の合計として約 $340 \mathrm{~m}$ 隆起したと見積もられる 一方, 「基本ケース」では $100 \mathrm{~m}$ 分は海退によるものであ るため, 隆起量が約 $240 \mathrm{~m}$ と「侵食のみ考慮ケース」に比 べて $100 \mathrm{~m}$ 少なく見積もられている.

前小節では, 生俵累層堆積後の隆起速度を議論したが, 「侵食のみ考慮ケース」での隆起速度を算出すると $0.1 \mathrm{~mm} /$ 年〜 $1.1 \mathrm{~mm} /$ 年となり,「基本ケース」と比べて隆起 速度が $40 \%$ 程度早くとなる。

なお, 本研究で使用した海水準変動曲線は, 主にヨーロ ッパとアメリカに分布する地層を対象にシーケンス層序 学的手法を用いて復元されたものである[30]. しかし，地 層の堆積年代等に誤差を含む可能性はあるため, 連続した データが取得されており地質年代も比較的明確にされて いる海洋底で掘削されたコアに含まれる有孔虫化石の酸 素同位体組成のデータなどを用いて, 海水準変動曲線の年 代をより確かなものにする等, 更なる精度の向上が必要で ある。 


\subsection{3 侵食量の影響}

次に, 侵食量が隆起・沈降量の見積もりにどの程度影響 するかを検討する.瑞浪層群堆積開始時から現在までの間, 一切の侵食が生じず, 不整合期においても削剥による層厚 の減少がなかった, すなわち, 現在観察される層厚が堆積 時の地層の厚さと同じであると仮定して, 隆起・沈降量の 見積もりを行った（ただし，海水準変動は考慮されている ため, 以下では, この見積もり結果を「海水準のみ考慮ケ 一ス」という). 月吉断層北側での見積もり結果を Fig.5 に示す（図中のム）。これと「基本ケース」の結果（Fig.4 および Fig.5 中の○）を比較すると, 侵食を考慮しない場 合には，不整合の下位層（生俵累層や明世累層）堆積時の 沈降量と不整合期の隆起量が小さいことがわかる（Fig. 5). 具体的には, 生俵累層堆積時の沈降量が「基本ケース」で は約 250m であるのに対して「海水準のみ考慮ケース」で は $133 \mathrm{~m}$ と見積もられた. また, 生俵累層堆積後の隆起量 は「基本ケース」では約 $240 \mathrm{~m}$ であるのに対して「海水準 のみ考慮ケース」では $125 \mathrm{~m}$ となった。「基本ケース」で は生俵累層堆積後の不整合期に約 $120 \mathrm{~m}$ 削剥されるので, その分が沈降量と隆起量から差し引かれている.「海水準 のみ考慮ケース」は現在認められる層厚分のみが堆積した との仮定に基づくため, 堆積時の地層の厚さは最も小さく 見積もられている。つまり「海水準のみ考慮ケース」では 隆起・沈降量として最小值を見積もっていることになる. 本研究では, 現在認められる地層の最大の厚さから侵食
量を見積もった。しかし, 最大層厚の分布域でも不整合期 に侵食を受けた可能性はある。このため, 隆起・沈降量を より精度よく求めるためには, 堆積時の地層の厚さや侵食 量の復元が必要である.

\section{2 隆起·侵食による地質環境の変化}

地下水の動きは主に動水勾配と岩盤自体の透水性に支 配されており,このうち, 動水勾配は地形に強く依存する. したがって, 隆起・侵食によって地形が変化すると, 動水 勾配の変化により地下水流動に変化が生じ, これによって 酸化還元環境などが変化する可能性がある.

現在の瑞浪層群中の地下水は, 水素・酸素同位体から天 水起源と考えられており, その滞留時間は数千年 1 万数 千年と推測されている[40]. 月吉鉱床が存在する地表下 130～150m の深度での瑞浪層群中の地下水の酸化還元電 位は約-360mV と測定されている[41]. このような強還元 環境は, 地層中の有機物を介した硫酸還元菌による硫酸還 元とそれに続く硫化鉱物の沈殿によって形成されている と考えられている[40]. この反応に使われる硫酸イオンは, 月吉鉱床においては, 地表近くの酸化帯が海成層に達する ことによって, 海成層に含まれる海成硫酸塩や硫化物から 形成されたものである可能性が指摘されている[40]. この ため, 瀬戸層群堆積後の隆起時に, 侵食がそれほど生じて おらず, 酸化帯や酸化的な地下水が海成層まで達していな い時期には, 月吉鉱床の存在深度には硫酸イオンが供給さ

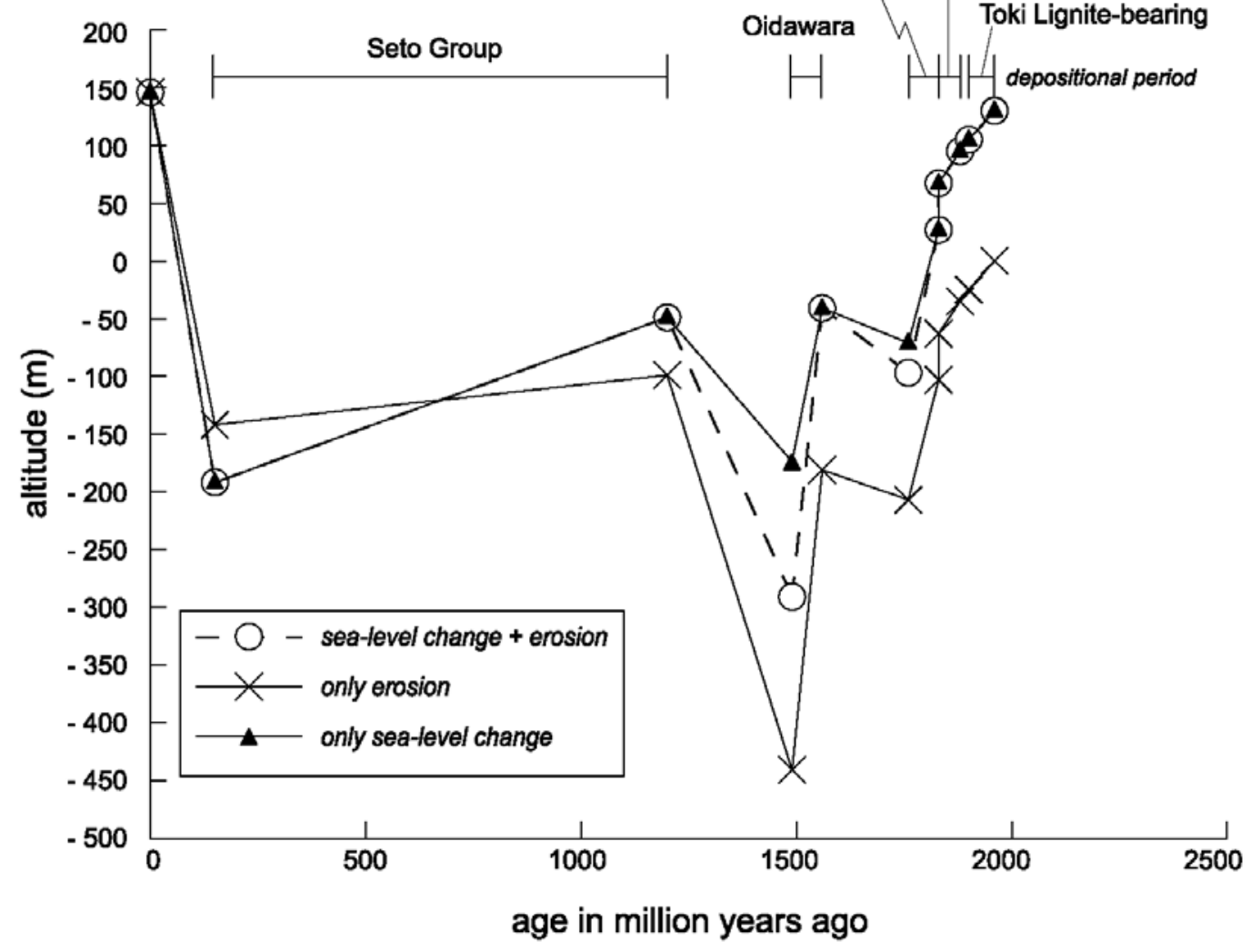

Fig. 5 Comparison of quantitative estimations using various assumptions. Lines indicate the change of the basal altitude of the Mizunami Group at the northern side of the Tsukiyoshi Fault. 
れず, 堆積岩中の地下水が現在と同じように淡水系であれ ば, 酸化還元環境を含む地質環境は現在のそれとは異なっ ていた可能性がある. また, 海成層堆積時の地下水が海水 系であった時期にも, 現在とは異なる地質環境にあった可 能性もある.

ところが, 現在の月吉鉱床の存在深度で生じていると考 えられている, 有機物を介した硫酸還元菌による酸化還元 反応は, 生俵累層堆積後の侵食期から現在まで継続してい ると考えられている[42]. さらに, 瑞浪層群上部の生俵累 層と明世累層には貝化石が含まれているが, これらの分布 域では, 現在の地表面から深度 20～60m までは貝化石が 溶脱しているものの, それ以深では溶脱していない[42]. この観察結果から, 地表下 $20 \sim 60 \mathrm{~m}$ 以深では, 炭酸塩鉱 物を保存する地質環境が, これらの地層の堆積時期から現 在まで保持されてきたことを示すものと考えられている [42]. これらの考察から, 本研究で隆起量が最も大きいと 見積もられた瀬戸層群堆積後から現在までの期間におい ても, 瑞浪層群中では, 隆起・侵食に起因する地質環境の 変化は地表近くに限定されていたことが示唆される.

ところで, 酸化還元環境の指標となる鉄鉱物に関しては, 瑞浪層群では現在の地表下 $20 \sim 30 \mathrm{~m}$ の範囲では水酸化鉄 の沈着が認められる一方で, 深度 $60 \mathrm{~m}$ 以深では還元状態 を示唆する黄鉄鉱が存在する.この黄鉄鉱のうち, 淡水成 層 (土岐夾炭累層と本郷累層) に産出する自形から半自形 の黄鉄鉱は, 海成層 (生俵累層と明世累層) 堆積後の侵食 期に, 天水起源の地下水と海水起源の地下水とが混合した 地下水が土岐夾炭累層に供給されることによって形成さ れたと考えられている[43]. その形成時期は続成作用の初 期段階で，海成層堆積後の隆起時期とされている[43]. ウ ラン濃度と黄鉄鉱の量の関係から, ウラン鉱化作用は淡水 成層中の自形から半自形の黄鉄鉱の形成と同時期に生じ たと推定されている[43]. つまり, 黄鉄鉱の形成とウラン 鉱化作用も隆起・侵食による地下水流動および地質環境の 変化に伴うものである可能性があり, ウラン鉱床を形成し た地質環境の形成にも隆起・侵食が関わっている可能性が 示唆される.

なお, 月吉鉱床における現在主な溶解度制限固相は $\mathrm{UO}_{2}$ (am)であること, その溶解度は $\mathrm{pH}$, 酸化還元電位のほか に炭酸ガス分圧に影響されるとされている[42]. これに基 づけば, 過去の $\mathrm{pH}$, 酸化還元電位, 炭酸ガス分圧を見積 もることによって, 地下水中へのウランの溶解度を推定す ることができ, 地質環境の変化がウランの移行・保持に及 ぼした影響を評価する際の一助となる.

\section{6 おわりに}

本論では, 月吉鉱床で掘削されたボーリング孔で観察さ れる累層および層群オーダーの地層の厚さに基づいて, 大
まかな見積もりではあるものの, 月吉鉱床における隆起・ 沈降量と約 150 年前から現在までの隆起速度を見積もつ た.この結果，現時点では約 150 万年前もしくは約 100 万年前と推定される瀬戸層群堆積後から現在まで期間の 隆起量が約 $340 \mathrm{~m}$ で最も大きく, この間の平均隆起速度は $0.2 \sim 0.3 \mathrm{~mm} /$ 年と見積もられた.

本研究で示したように, 隆起・侵食は約 1000 万年前と 考えられる月吉鉱床の形成の前から現在に至るまで繰り 返し起こっていたと考えられる.このような変動を長期的 に被りながらもウラン鉱床は長期間にわたって保存され てきており，隆起・侵食の影響はウラン鉱床の存在深度に までは達しなかったものと考えられる．このことから，長 期の時間スケールで生じる地質学的変動の影響下におい ても，地質環境が放射性核種を保持する能力を有すること が事例として示されたと考えている.

しかし, 隆起・侵食と, ウラン鉱床を保存してきた地質 環境の形成・保持との関係は明らかにされていない. 今後, 隆起・侵食に伴う地下水流動系の変化や, 地球化学環境の 形成・保持のメカニズムを明らかにし, 隆起・侵食に伴う 地質環境の変化やその影響範囲を具体的に示すとともに, このような知見を性能評価モデルに反映することにより， 地層処分システムの長期的安全性の信頼性の向上に資す ることが重要である.

\section{謝辞}

核燃料サイクル開発機構東濃地科学センターの岩月輝 希博士, 村上由記博士, 新里忠史氏 (現幌延深地層研究セ ンター)には日頃から研究内容について議論して頂いてい る.また, 2 名の匿名査読者からは, 細部にまでわたって 本稿の改善に大変有益かつ詳細なご指摘をいただきまし た. 以上の方々に深く感謝致します.

\section{参考文献}

[1] 太田久仁雄, 湯佐泰久 : 放射性廃棄物地層処分の概念 とナチュラルアナログ研究の役割. 資源環境地質学 : 地球史と環境污染を読む, 資源地質学会, 東京, pp.379-386 (2003).

[2] 核燃料サイクル開発機構: わが国における高レベル放 射性廃棄物地層処分の技術的信頼性一地層処分研究 開発第 2 次取りまとめ一(総論). 核燃料サイクル開発 機構技術資料 JNC TN1400 99-020 (1999).

[3] 糸魚川淳二 : 瑞浪地域の地質. 瑞浪市化石博物館専報 no.1, 50p. (1980).

[4] Yusa, Y., Ishimaru, K., Ota, K., Umeda, K. : Geological and geochemical indicators of paleohydrogeology in Tono uranium deposits, Japan. In: Paleohydrogeological methods and their applications. Proceeding of an NEA 
Workshop, Paris (France), 9-11 November 1992, pp.117-146 (1993).

[5] 陶土団体研究グループ: 断層境界を伴う多数の基盤ブ ロックからなる内陸盆地一岐阜県多治見市周辺の東 海層群堆積盆地の例一. 地球科学 53, 291-306 (1999).

[6] Suzuki, K., Adachi, M. : Denudation history of high T/P Ryoke metamorphic belt, southwest Japan: constraints from CHIME monazite ages of gneisses and granitoids. Journal of Metamorphic Geology 16, 22-37 (1998).

[7] 氏原 温, 入月俊明, 細山光也 : 岐阜県東濃地域の新 第三系. 日本地質学会第 106 年学術大会見学旅行案内 書, pp.97-116 (1999).

[8] 石原舜三, 鈴木淑夫 : 東濃地方ウラン鉱床の基盤花崗 岩. 地質調査所報告 no.232, 113-127 (1969).

[9] Hayashida, A. : Timing of rotational motion of Southwest Japan inferred from paleomagnetism of the Setouchi Miocene Series. Journal of Geomagnetism and Geoelectricity 38, 295-310 (1986).

[10] 竹内 章 : 日本列島のネオテクトニクスと構造区. 月 刊地球 21, 537-542 (1999).

[11] 動力炉・核燃料開発事業団 : 日本のウラン資源. 動力 炉・核燃料開発事業団技術資料, PNC PN7420 94-006 (1999).

[12] 小室光世, 山本正博, 鈴木 滋, 野原 壯, 武田精 悦: 東濃地域月吉鉱床におけるウランの産状. 鉱山地 質 40, 44 (1990).

[13] 小室光世, 大塚保夫, 山本正博 : 東濃地域月吉鉱床に おけるウランの産状 (その 2)-Fe-Ti 酸化鉱物および 輝沸石に伴うウランについて一. 鉱山地質 41, 177 (1991).

[14] 堀川循正, 小室光世 : 東濃地域月吉鉱床におけるウラ ンの産状 (その 3 ) 一有機物に伴うウランについて一. 資源地質学会第 46 回年会講演会講演要旨集 p.86 (1996).

[15] Ochiai, Y., Yamakawa, M., Takeda, S., Harashima, F. : Natural analogue study on Tono uranium deposit in Japan. In: CEC Natural analogue working group, Third Meeting, Snowbird, USA, 15-17 June 1988, CEC Nuclear Science and Technology Series, EUR 11725, 126-138 (1989).

[16] Nohara, T., Ochiai, Y., Seo, T., Yoshida, H. : Uranium-series disequilibrim studies in the Tono uranium deposit, Japan. Radiochimica Acta 58/59, 409-413 (1992).

[17] Yoshida, H. : Relation between U-series nuclide migration and microstructural properties of sedimentary rocks. Applied Geochemistry 9, 479-490 (1994).

[18] Yoshida, H., Kodama, K., Ota, K. : Role of microscopic flow-paths on nuclide migration in sedimentary rocks - A case study from the Tono uranium deposit, central Japan. Radiochimica Acta 66/67, 505-511 (1994).

[19] Yoshida, H., Yui, M., Shibutani, T. : Flow-path structure in relation to nuclide migration in sedimentary rocks - An approach with field investigations and experiments for uranium migration at Tono uranium deposit, central Japan. Journal of Nuclear Science and Technology 31, 803-812 (1994).

[20] 赤嶺秀雄 : 瀬戸市を中心とする陶土地帯の地質, 特に 陶土および亜炭を含む地層の堆積状態について. 資 源科学研究所彙報, 34, 25-39 (1954).

[21] Saito, T. : Miocene Planktonic Foraminifera from Honshu, Japan. Sci. Rep. Tohoku Univ., Second Ser. (Geology), 35, 123-209 (1963).

[22] Cande, S.C., Kent, D.V. : Revised calibration of the geomagnetic polarity timescale for the Late Cretaceous and Cenozoic. Journal of Geophysical Research, 100, 6093-6095 (1995).

[23] Hiroki, Y., Matasumoto, R : Magnetostratigraphic correlation of Miocene regression-and-transgression boundaries in central Japan. Journal of Geological Society of Japan, 105, 87-107 (1999).

[24] 小林孝男: 岐阜県可児盆地東部の地質とウラン鉱化作 用. 鉱山地質 39, 79-94 (1989).

[25] Gladenkov, A.Y. : Oligocene and lower Miocene diatom zonation in the North Pacific. Stratigraphy and Geological Correlation, 6, 150-163 (1998).

[26] 斎藤常正: 最近の古地磁気層序の改訂と日本の標準微 化石層序. 石油技協会誌, 64, 2-15 (1999).

[27] 伊奈治行, 1981, 瑞浪層群の化石 1. 可児 - 瑞浪盆 地の植物. 瑞浪市化石博専報, no.2, 20p. (1981).

[28] 山野井徹 : 新第三紀における日本島の古植生. 月刊地 球 16, 180-185 (1994).

[29] 鹿野勘次 : 岐阜県美濃加茂盆地の下部中新統瑞浪層群 のフィッション・トラック年代. 美濃加茂市民ミュー ジアム紀要, 第 2 集, 1-8 (2003).

[30] Haq, B.U., Hardendol, J., Vail, P.R. : Chronology of fluctuating sea levels since Triassic. Science 235, 1156-1167(1987).

[31] 糸魚川淳二, 柴田 博 : 瀬戸内区の中新世古地理 (改 訂版). 瑞浪市化石博物館研究報告, no.19, 1-12 (1992).

[32] 瀬戸浩二 : 瑞浪層群の底生有孔虫化石群集. 瑞浪市化 石博物館研究報告, no.19, 165-191 (1992).

[33] 天野和孝, 野中孝彦: 貝化石群集の群集構造による古 水深の推定方法一中新統瑞浪層群産貝化石群集を例 として一. 化石, no. 70, 23-34.

[34] 森山昭雄: 中部山岳地域における山地形成の時代性一 山はいつ高くなったか? 一. 大学テキスト 変動地 形学, 古今書院, 東京, pp.87-109 (2001).

[35] 中山勝博, 陶土団体研究グループ : 瀬戸層群の堆積盆 地. 地球科学 43, 392-401 (1989).

[36] 郡谷順英, 野原 壯, 鈴木元孝 : 稠密なボーリングコ アデータから推定できる月吉断層の形態と活動履歴 について. 地球惑星関連学会 2003 年合同学会要旨集 CD-ROM, G015-P003 (2003).

[37] 木曾敏行：木曾川隆起の地形発達. 地理学評論 36, 
86-109 (1963).

[38] 森山昭雄, 丹羽正則 : 土岐面 - 藤岡面の対比と土岐面 形成に関連する諸問題. 地理学評論 58, 275-294 (1985).

[39] 藤原 治, 柳田 誠, 三箇智二: 日本列島の最近約 10 万年間の隆起速度の分布. 月刊地球， 26, 442-447 (2004).

[40] 岩月輝希, 村上由記, 長沼 毅, 濱 克宏 : ウラン鉱 床の長期保存に係わる岩盤の酸化還元緩衝能力一東 濃地域における天然環境の水一鉱物一微生物システ 么の研究例一. 地球化学 37, 71-82 (2003).

[41] Japan Nuclear Cycle Development Institute : H12 project to establish technical basis for HLW disposal in Japan -Supporting Report 1 Geological environment in Japan-. JNC Technical Report JNC TN1400 2000-002 (2000).

[42] Iwatsuki, T., Arthur, R., Ota, K., Metcalfe, R. : Solubility constraints on uranium concentrations in groundwaters of the Tono uranium deposits, Japan. Radiochimica Acta 92, 789-796 (2004).

[43] Shikazono, N., Nakata, M. : Compositional variation of pyrite, diagenetic alteration and genesis of Tono sandstone-type uranium deposits in Japan. Resource Geology Special Issue no.20, 55-64 (1999). 
